\title{
Efficiency of using Polymer Impregnated Porous Concrete in Structural Engineering Applications
}

\author{
Sameh Yehia* and Mona M. Fawzy \\ Higher Institute of Engineering, El-Shorouk Academy, Cairo, Egypt \\ Accepted 18 March 2017, Available online 20 March 2017, Vol.7, No.2 (April 2017)
}

\begin{abstract}
This paper presents a focused study on properties of porous concrete to widen its application to structural engineering. Mechanical properties like compressive strength, indirect tensile strength, flexural strength and physical properties like density, permeability and porosity are studied. To determine those parameters, twenty-seven cubes, cylinders and prisms were tested. Also, three polymer impregnated porous concrete slabs were tested under pure bending moment to study the efficiency of selected resin to integrate particle of concrete to achieve a new generation in using porous concrete in structural engineering. Three different cement content specimens of porous concrete were considered, studied cement contents are $200 \mathrm{~kg} / \mathrm{m}^{3}, 300 \mathrm{~kg} / \mathrm{m}^{3}$ and $400 \mathrm{~kg} / \mathrm{m}^{3}$. The results show that, increasing the cement content can increase the compressive strength, indirect tensile strength and flexural strength. Density of porous concrete is less than conventional concrete by $21 \%$ but permeability factor recorded higher value compared to conventional concrete by sixteen times. Increasing the cement content has no significant effect on either ultimate load or maximum deflection of polymer impregnated porous concrete slabs but the results recorded an achievement to use this concrete in structural engineering applications and give an easy way to cast special concrete like polymer concrete without special tools.
\end{abstract}

Keywords: Porous Polymer Concrete, Mix Design, Mechanical and Physical Properties, Structural Application of Porous Concrete, Unreinforced Slab.

\section{Introduction}

Porous concrete is a special type of advanced concrete, it is a high porosity concrete used for outdoor flatwork (public works) that allows water to pass through it. It is a low water/cement ratio, low slump mix consisting of cement, narrowly graded coarse aggregate, little or no fine aggregate, water and admixtures. It is held together by cementitious paste at the coarse aggregate contact points since there is limited paste and fine aggregate to fill the voids between the coarse aggregate. The amount of water used in a mix is highly critical. Too much water and the mix will segregate; too little water will lead to balling in the mixer and slow unloading times. The perfect and ideal amount of water will impart a wet metallic appearance or sheen. Squeezing and releasing a handful of the mix should result in a mix that neither crumbles (too dry) nor lose its structure as paste flows away from the aggregates (too wet). Too little water can also hinder curing of the concrete and could lead to premature raveling of the surface. The actual mix proportions for porous concrete varies depending on the application, mechanical properties required and materials used.

*Corresponding author Sameh Yehia and Mona M. Fawzy are working as Assistant Professors

DOI: http://Dx.Doi.Org/10.14741/Ijcet/22774106/7.2.2017.16
Admixtures are often used to control the normal rapid setting of porous concrete. They are used to increase workability, allow concrete to easily move out of the mixer, and control the setting time so the mix may be placed correctly. The following Table 1 provides some material ranges as well as more typical use to help mix designer. Nowadays, special concrete is highly recommended and can help us to cast new buildings with new enhanced features, from that the aim of research came.

Table 1: Mix Proportions for Porous Concrete

\begin{tabular}{|c|c|c|c|}
\hline $\begin{array}{l}\text { Proportion } \\
\text { of Mixes }\end{array}$ & $\begin{array}{l}\text { Proportion } \\
\text { Range } \\
\text { (W. R. } \\
\text { Grace\&Co.- } \\
\text { Conn, 2006) }\end{array}$ & $\begin{array}{c}\text { Typical } \\
\text { Proportions } \\
\text { (W. R. } \\
\text { Grace\&Co.- } \\
\text { Conn, 2006) }\end{array}$ & $\begin{array}{c}\text { Proportion } \\
\text { Range } \\
\text { (Axim, } \\
\text { 2006) }\end{array}$ \\
\hline $\begin{array}{l}\text { Cementitious } \\
\text { Material }\end{array}$ & $\begin{array}{c}270 \text { to } 415 \\
\mathrm{~kg} / \mathrm{m}^{3}\end{array}$ & $\begin{array}{c}325 \text { to } 400 \\
\mathrm{~kg} / \mathrm{m}^{3}\end{array}$ & $\begin{array}{c}224 \text { to } 388 \\
\mathrm{~kg} / \mathrm{m}^{3}\end{array}$ \\
\hline Coarse Aggregate & $\begin{array}{l}1190 \text { to } \\
1600 \mathrm{~kg} / \mathrm{m}^{3}\end{array}$ & $\begin{array}{l}1400 \text { to } 1550 \\
\mathrm{~kg} / \mathrm{m}^{3}\end{array}$ & $\begin{array}{c}1431 \text { to } \\
1670 \mathrm{~kg} / \mathrm{m}^{3}\end{array}$ \\
\hline $\begin{array}{c}\text { Water/cementitious } \\
\text { Ratio }\end{array}$ & 0.20 to 0.45 & 0.27 to 0.30 & 0.27 to 0.38 \\
\hline Admixtures & $\begin{array}{l}200 \text { to } 400 \\
\mathrm{ml} / 100 \mathrm{~kg}\end{array}$ & $\begin{array}{c}300 \\
\mathrm{ml} / 100 \mathrm{~kg}\end{array}$ & $\begin{array}{l}200 \text { to } 400 \\
\mathrm{ml} / 100 \mathrm{~kg}\end{array}$ \\
\hline Permeability & $\begin{array}{l}100 \text { to } 900 \\
\mathrm{~L} / \mathrm{min} / \mathrm{m}^{2}\end{array}$ & $\begin{array}{c}500 \\
\mathrm{~L} / \mathrm{min} / \mathrm{m}^{2}\end{array}$ & $\begin{array}{c}200 \\
\mathrm{~L} / \mathrm{min} / \mathrm{m}^{2}\end{array}$ \\
\hline Void Content & $15 \%$ to $35 \%$ & $20 \%$ to $30 \%$ & 13 to $30 \%$ \\
\hline
\end{tabular}


As the void content increases, the water drainage rate through the concrete also increases and this option can be use later to increase resin content in polymer impregnated concrete. If more strength is needed, a small amount of fine aggregate could be added to the mix, but this will reduce the void content and its permeability. Typical compressive strength ranges between 35 to $280 \mathrm{~kg} / \mathrm{cm}^{2}$, and mostly compressive strength $170 \mathrm{~kg} / \mathrm{cm}^{2}$ is common. Slump is usually less than $20 \mathrm{~mm}$. Chemical admixtures are used to affect the water/cementitious ratio, influence workability and setting times and enhance mechanical properties and durability. Porous concrete has an interconnected pore structure that freely allows the passage of water to flow through also, it's not easy to manufacture polymer concrete because it needs special labors and machines. Pore porous concrete structure option will be helping in installing resin to widen the application of porous concrete from public works (pavements) to structural applications (reliable unreinforced concrete slab).

\section{Objective}

This paper covers some of the main properties and uses of traditional porous concrete and its ecofriendly use in structural applications. This concrete may be very beneficial if it is utilized to its full extent in structural applications. The most important parameter studied in this paper is changing the percentage of cement content. This parameter plays the leading role in the performance of any concrete mix. Compressive strength, indirect tensile strength and flexural strength are measured after seven days, fourteen and twentyeight days in addition to density. Permeability for cast slab specimens were calculated by Darcy's Law and porosity experimentally calculated then slabs integrated with resin to study the flexural behavior and its resistance in structural applications. Finally, comparisons were took place to study the relationship between properties and different factors.

\section{Experimental Work Program}

\subsection{Introduction}

Two phases were took place in this research. First Phase, three slabs were cast with $10 \mathrm{~cm}$ thickness, 50 $\mathrm{cm}$ length and width, in additional to nine cubes $15 \times 15 \times 15 \mathrm{~cm}$, cylinders $15 \times 30 \mathrm{~cm}$ and prisms $10 \times 10 \times 50 \mathrm{~cm}$ for each trial mix. Second Phase, the research focused on studying the structural behavior of polymer impregnated porous concrete. Accordingly, resin was used to fill the voids partially in porous concrete to increase capability of sustained load, which will help to reliability use of this concrete in structural applications.

\subsubsection{Details of Concrete Specimens}

The specimens of porous concrete were mixed with three different cement content, 200, 300, and $400 \mathrm{~kg} / \mathrm{m}^{3}$. The water cement ratio and coarse aggregate in all concrete mixes were 0.30 and
$1500 \mathrm{~kg} / \mathrm{m}^{3}$, respectively. (Viscocrete Admixture) was used as admixture to enhance fresh concrete performance; the added dose is equal to $300 \mathrm{ml} / 100 \mathrm{~kg}$ cement. Table (2) shows the proportions of concrete mixes.

Testing of porous concrete specimens were carried out after curing for seven days, fourteen days and twenty-eight days. Curing were took place after twenty-four hours with spraying mode and specimens were covered with burlap. Cubes were tested for compressive strength, cylinders for indirect tensile strength and finally prisms for flexural strength. Tests were carried out according to (BS EN 5328).

Table 2: Concrete Mix Design Proportions

\begin{tabular}{|c|c|c|c|c|c|}
\hline 选 & 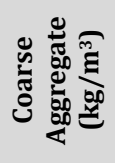 & 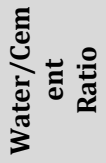 & 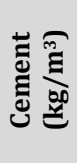 & 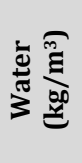 & 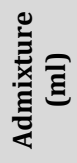 \\
\hline Mix (A) & 1500 & 0.30 & 200 & 60 & 600 \\
\hline Mix (B) & 1500 & 0.30 & 300 & 90 & 900 \\
\hline $\operatorname{Mix}(C)$ & 1500 & 0.30 & 400 & 120 & 1200 \\
\hline
\end{tabular}

\subsection{Manufacturing Procedures of Specimens}

Thin layer of oil was applied to cover slab wooden mold to easily fabricate porous concrete slab. The mixing process were took place as usual by using concrete mixer. Fresh concrete was mixed with water plus admixtures then fresh concrete was poured in wooden molds by batching mode without compaction. Finally, specimens were leveled from top to get the same level of concrete surface. As shown in Figure (1) the specimens were casted and ready for curing by spraying mode.

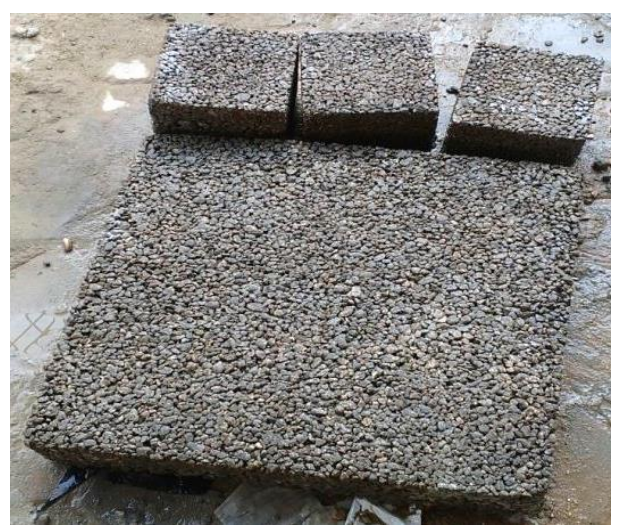

Figure 1: Final Specimens

\subsection{Testing of Phase One Specimen}

Cubes were tested under axial compression, cylinders were tested under indirect tension and finally prisms were tested under pure bending moment. Testing machine of capacity 50 ton was used. Testing process was carried out in accordance with (BS EN 12390:2009). 


\subsubsection{The permeability test for cast concrete slab specimen (without resin)}

Permeability can be defined as the property that governs the rate of flow of a fluid into a porous solid. The concrete slabs were tested after twenty-eight days to obtain the following factors which are included in the shown equation (1) (Darcy's law) (Toy, 1924) to calculate permeability factor of tested slab under steady state flow. The coefficient of permeability $\mathrm{K}$ is determined as:

$\mathrm{Dq} / \mathrm{dt}=\mathrm{K}(\Delta \mathrm{H} \mathrm{A}) /(\mathrm{Lv})$

\section{Where}

$\mathrm{Dq} / \mathrm{dt}$ : is the rate of fluid flow.

$\Delta \mathrm{H}$ : the pressure gradient.

A: the surface area.

L: the thickness of the solid.

$v$ : the viscosity of the fluid.

It is worth to be mentioned that, cylindrical tube with known diameter $(20 \mathrm{~cm})$ was used to fill it with water and control effected area (A) and this process are normally carried out for any test of permeability.

\subsection{Preparing Polymer Impregnated Concrete Slab Specimens}

In this phase, cement mortar was used to cover the specimen from four sides and bottom of slab to act as a closed box; which helped to filling slab specimens with partially resin (J-FIX Polyester Resin). The porosity (voids \%) of porous concrete is measured by filling the slab specimens with fully water and water volume was observed to obtain porosity and to ensure a closed box action before pouring resin. The detected value is approximately $30 \%$ of total volume of specimen. The volume of resin was stacked in all slab specimens and covered by $75 \%$ of total volume of voids percentage. Figures (2) and (3) show the process of mortaring from outside and filling slab specimens with resin. Pouring process was carried out regularly with different layers to ensure great integrity between concrete ingredients. Finally, specimens were tested under two static loads for flexure behavior. Figure (4) represents the final slab specimen before testing. Also, Figure (5) shows scheme to present ingredients of concrete.

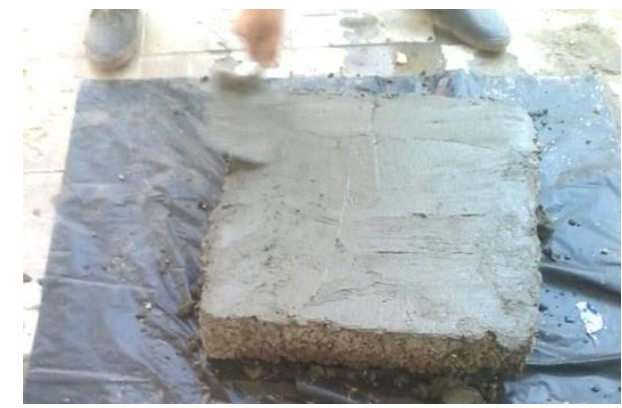

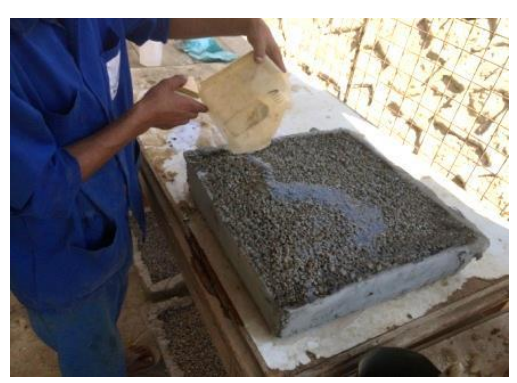

Figure 3: Pouring Polyester for Slab Specimen

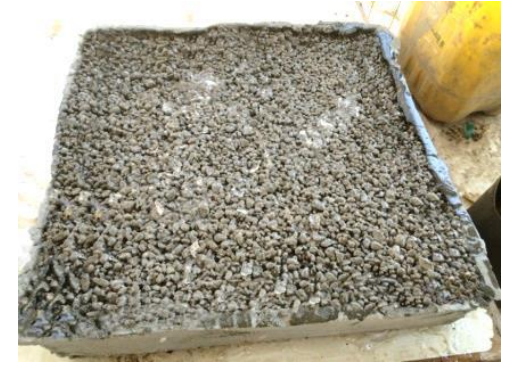

Figure 4: Final Shape of Polymer Slab Specimen

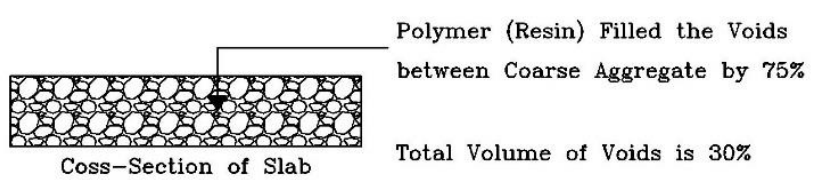

Figure 5: Porous Concrete Scheme

\subsection{Testing of Polymer Impregnated Concrete Slab Specimens}

Three polymer slab specimens were tested under effect of two static loads causing pure bending moment at the middle of specimens as shown in Figure (6). Each slab had different cement content. S-1 had cement content equal to $200 \mathrm{Kg} / \mathrm{m}^{2}, \mathrm{~S}-2$ had cement content equal to $300 \mathrm{Kg} / \mathrm{m}^{2}$ and S-3 had cement content equal to 400 $\mathrm{Kg} / \mathrm{m}^{2}$. Deflection was measured by LVDT device which was fixed at the middle of clear span. Cracks were observed and recorded to identify the failure type for each specimen.

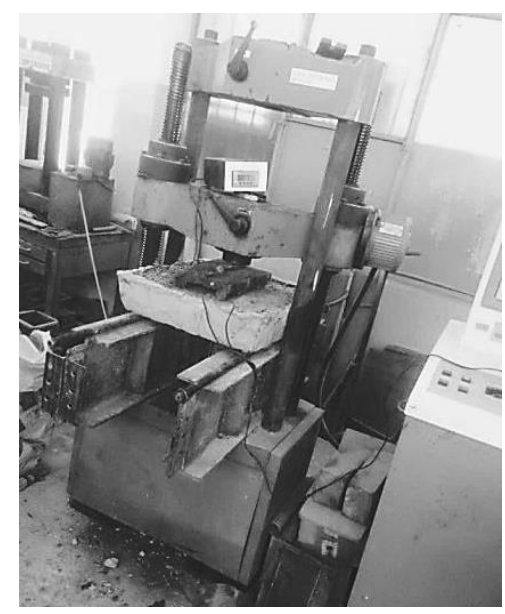

Figure 6: Test Setup for Specimens

Figure 2: Slab Specimen Mortaring 


\section{Results and Discussions}

Test results are summarized in Tables (3) and (4). It is clear from Table (3) that the density of traditional concrete is higher than porous concrete by $26 \%$ also, the permeability of porous concrete is higher than traditional concrete by about sixteen times. The permeability and void percentage values are compatible with equation of A Contribution from ACI Committee 236 (Bentz \& Sumanasooriya, 2010).

Table (4), shows the results for specimens (cubes, cylinders and prisms) after seven, fourteen and twenty eight days with different cement contents. Cubes, cylinders and prisms were tested to get compressive strength, indirect tensile strength and flexure strength, respectively. Mix (B) and (C) give compressive strength, indirect tensile strength and flexural strength more than Mix (A) by approximately 198\% and 378\% for compressive strength, $266 \%$ and $500 \%$ for indirect tensile strength, $233 \%$ and $416 \%$ for flexural strength, respectively so that, the results of the tests show that increasing the cement content enhances the properties of the porous concrete. The increasing in cement content by $50 \mathrm{~kg} / \mathrm{m}^{3}$ can enhance the properties of porous concrete by approximately 288\%, 383\%, 324\% for compressive strength, indirect tensile strength and flexural strength, respectively. It's observed that indirect tensile strength and flexural strength are ranged by $(6 \%$ to $9 \%)$ and $(8 \%$ to $10 \%)$ as a percentage of compressive strength value. The recorded value for indirect tensile strength like traditional concrete on the other hand the value related to flexural strength is very low percentage compared to traditional concrete (Yehia, 2015) this due to missing of fine aggregate (sand) which is fill the voids between coarse aggregate and give concrete ingredients more integrity.

Figure (7) shows the effect of increasing the cement content on the compressive strength at different concrete age also figure (8) presents the relationship between cement content and indirect tensile strength at different concrete ages. Finally, Figure (9) shows different flexural strengths that correspond to various cement contents at different concrete age. All those figures confirm the above analysis and gives clear indication about different relationships of mechanical properties of tested specimens.

Table 3: Density of Tested Concrete Specimens

\begin{tabular}{ccc}
\hline Concrete Type & Density $\left(\mathrm{t} / \mathbf{m}^{3}\right)$ & $\begin{array}{c}\text { Permeability } \\
(\mathbf{c m} / \mathbf{s e c})\end{array}$ \\
\hline $\begin{array}{c}\text { Traditional } \\
\text { Concrete } \\
\text { as Reference }\end{array}$ & 2.25 & $\mathbf{6 \times 1 0} \mathbf{1 0}^{-11}$ \\
Porous Concrete* & 1.78 & $\mathbf{9 . 6} \times \mathbf{1 0}-10$ \\
\hline \multicolumn{2}{c}{$*$ Calculated as a average of tested specimens }
\end{tabular}

Table 4: Experimental Results of Tested Concrete Specimens

\begin{tabular}{|c|c|c|c|c|}
\hline 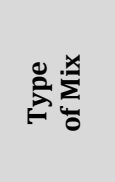 & 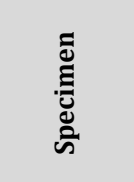 & 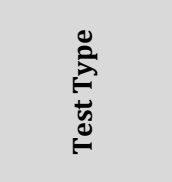 & 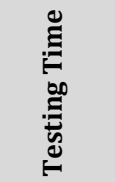 & 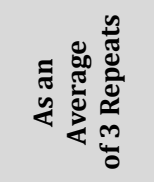 \\
\hline \multirow{3}{*}{ 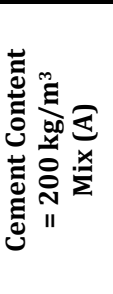 } & Cubes & $\begin{array}{l}\text { Compressive } \\
\text { Strength }\end{array}$ & $\begin{array}{l}7 \text { Days } \\
14 \text { Days } \\
28 \text { Days }\end{array}$ & $\begin{array}{l}37 \mathrm{~kg} / \mathrm{cm}^{2} \\
46 \mathrm{~kg} / \mathrm{cm}^{2} \\
59 \mathrm{~kg} / \mathrm{cm}^{2}\end{array}$ \\
\hline & Cylinders & $\begin{array}{l}\text { Indirect } \\
\text { Tensile } \\
\text { Strength }\end{array}$ & $\begin{array}{l}7 \text { Days } \\
14 \text { Days } \\
28 \text { Days }\end{array}$ & $\begin{array}{l}2 \mathrm{~kg} / \mathrm{cm}^{2} \\
3 \mathrm{~kg} / \mathrm{cm}^{2} \\
4 \mathrm{~kg} / \mathrm{cm}^{2}\end{array}$ \\
\hline & Prisms & $\begin{array}{l}\text { Flexural } \\
\text { Strength }\end{array}$ & $\begin{array}{l}7 \text { Days } \\
14 \text { Days } \\
28 \text { Days }\end{array}$ & $\begin{array}{l}3 \mathrm{~kg} / \mathrm{cm}^{2} \\
4 \mathrm{~kg} / \mathrm{cm}^{2} \\
5 \mathrm{~kg} / \mathrm{cm}^{2}\end{array}$ \\
\hline \multirow{3}{*}{ 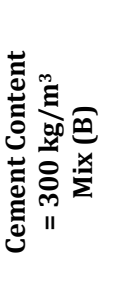 } & Cubes & $\begin{array}{l}\text { Compressive } \\
\text { Strength }\end{array}$ & $\begin{array}{l}7 \text { Days } \\
14 \text { Days } \\
28 \text { Days }\end{array}$ & $\begin{array}{c}73 \mathrm{~kg} / \mathrm{cm}^{2} \\
97 \mathrm{~kg} / \mathrm{cm}^{2} \\
120 \mathrm{~kg} / \mathrm{cm}^{2}\end{array}$ \\
\hline & Cylinders & $\begin{array}{l}\text { Indirect } \\
\text { Tensile } \\
\text { Strength }\end{array}$ & $\begin{array}{l}7 \text { Days } \\
14 \text { Days } \\
28 \text { Days }\end{array}$ & $\begin{array}{c}6 \mathrm{~kg} / \mathrm{cm}^{2} \\
8 \mathrm{~kg} / \mathrm{cm}^{2} \\
10 \mathrm{~kg} / \mathrm{cm}^{2}\end{array}$ \\
\hline & Prisms & $\begin{array}{l}\text { Flexural } \\
\text { Strength }\end{array}$ & $\begin{array}{l}7 \text { Days } \\
14 \text { Days } \\
28 \text { Days }\end{array}$ & $\begin{array}{c}7 \mathrm{~kg} / \mathrm{cm}^{2} \\
9 \mathrm{~kg} / \mathrm{cm}^{2} \\
12 \mathrm{~kg} / \mathrm{cm}^{2}\end{array}$ \\
\hline \multirow{3}{*}{ 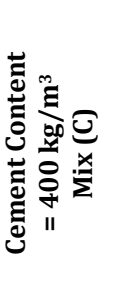 } & Cubes & $\begin{array}{c}\text { Compressive } \\
\text { Strength }\end{array}$ & $\begin{array}{l}7 \text { Days } \\
14 \text { Days } \\
28 \text { Days }\end{array}$ & $\begin{array}{l}140 \mathrm{~kg} / \mathrm{cm}^{2} \\
165 \mathrm{~kg} / \mathrm{cm}^{2} \\
205 \mathrm{~kg} / \mathrm{cm}^{2}\end{array}$ \\
\hline & Cylinders & $\begin{array}{l}\text { Indirect } \\
\text { Tensile } \\
\text { Strength }\end{array}$ & $\begin{array}{l}7 \text { Days } \\
14 \text { Days } \\
28 \text { Days }\end{array}$ & $\begin{array}{l}12 \mathrm{~kg} / \mathrm{cm}^{2} \\
15 \mathrm{~kg} / \mathrm{cm}^{2} \\
18 \mathrm{~kg} / \mathrm{cm}^{2}\end{array}$ \\
\hline & Prisms & $\begin{array}{l}\text { Flexural } \\
\text { Strength }\end{array}$ & $\begin{array}{l}7 \text { Days } \\
14 \text { Days } \\
28 \text { Days }\end{array}$ & $\begin{array}{l}13 \mathrm{~kg} / \mathrm{cm}^{2} \\
16 \mathrm{~kg} / \mathrm{cm}^{2} \\
21 \mathrm{~kg} / \mathrm{cm}^{2}\end{array}$ \\
\hline
\end{tabular}

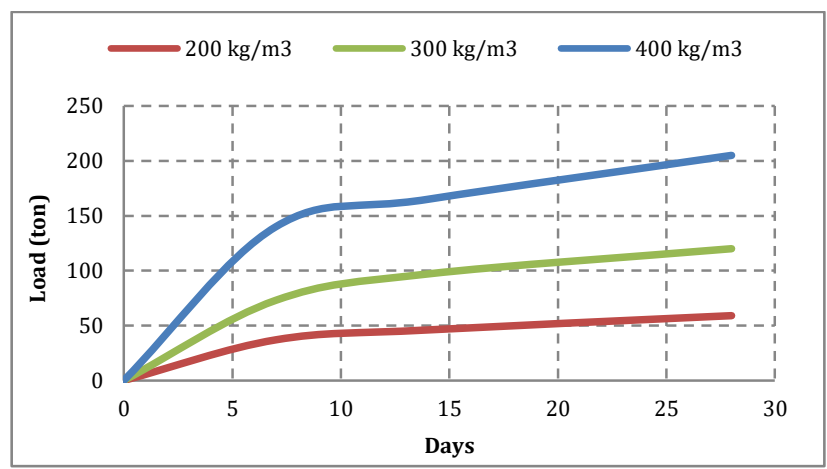

Figure 7: Relationship between Compressive Strength and Concrete Age using Different Cement Content

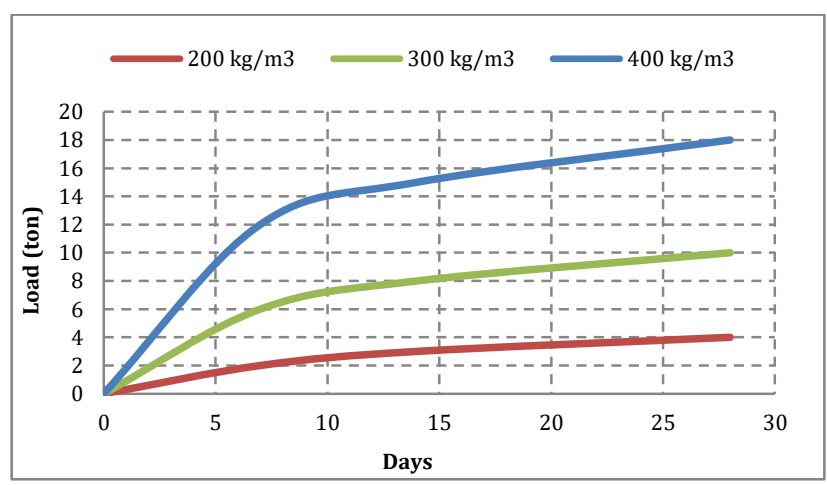

Figure 8: Relationship between Indirect Tensile Strength and Concrete Age using Different Cement Content 


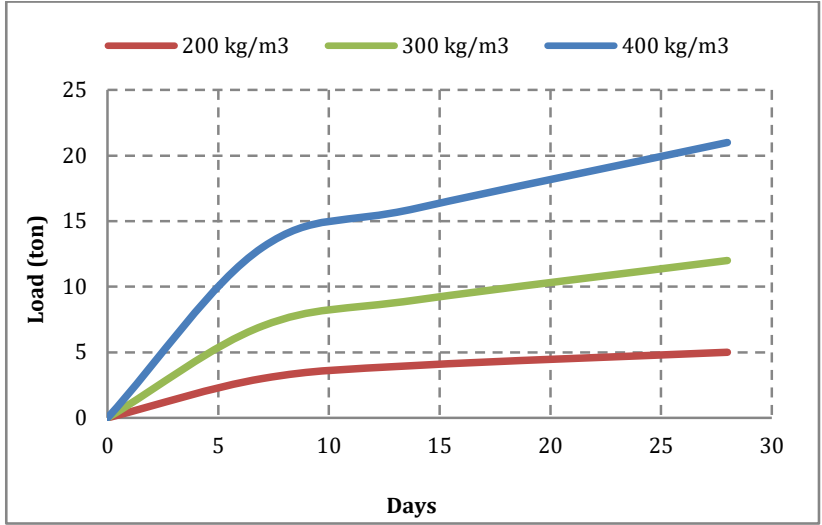

Figure 9: Relationship between Flexural Strength and Concrete Age using Different Cement Content

Table (5) and Figure (10) represent the ultimate load for polymer impregnated slab specimens versus deflection. Changing the cement content has no significant effect on either the ultimate load or deflection so that, it's recommended to use less cement content to be more economic without any significant lose in ultimate load capacity. The ultimate load ranged from 6.48 to 7.40 tons, while the maximum deflection was around $5 \mathrm{~mm}$. All three slabs showed the same behavior of load versus deflection, where an elastic behavior control the relationship curve up to cracking load, then resin (polymer material) effect became apparent and modulus of elasticity increased. Finally, propagation of cracks increased and when the ultimate load was reached the failure occur with large deflection record.

As shown in figure (10), first crack in slab (S-1) occurred at load 2.09 tons and propagation increased to load 3.10 tons then failure occurred at load 6.48 tons with shallow cracks in middle bottom of slab. Cracks in second slab (S-2) occurred at loads 2.20 tons and 3.00 tons, respectively. Meanwhile, failure occurred at 6.80 tons with deep cracks in middle bottom of slab. Three different cracks occurred at third slab (S-3), the first at load 2.50 ton, second at load 3.60 tons then at load 4.90 tons. Failure approximately occurred at load 7.40 tons in middle bottom of slab which is the maximum value of all three slabs. Cracks in (S-3) are more wide than others, this is due to lately state of deboning of concrete ingredients due to large cement content (strong cement paste) which happen suddenly in failure stage. The test of specimens can prove that, polymer filler material (resin) provide specimens more capability of sustained load. The percentage ratio between ultimate loads to failure loads is $33 \%$ as an average value of tested specimens also, displacement ductility factor recorded a value of $257 \%$ as an average of tested specimens, this calculated values give an indication for failure mode and can be classify as ductile failure mode mixed with flexural failure due to propagation of middle bottom crack up to failure (Ali, T., \& Yehia, S., 2016) as shown in Figure (11) which is shows the crack of bottom of slabs.

Table 5: Experimental Results of Tested Slab Specimens

\begin{tabular}{|c|c|c|c|c|c|}
\hline $\begin{array}{l}\text { ฮี } \\
\text { ฮั } \\
\text { के }\end{array}$ & 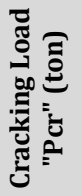 & 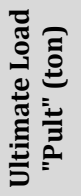 & 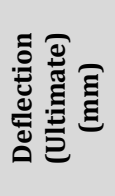 & $\underbrace{e^{a}}_{\substack{0 \\
\vdots \\
0}}$ & 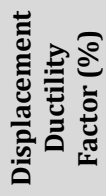 \\
\hline S-1 & 2.09 & 6.48 & 5.47 & $32 \%$ & $297 \%$ \\
\hline S-2 & 2.20 & 6.80 & 5.42 & $32 \%$ & $264 \%$ \\
\hline S-3 & 2.50 & 7.40 & 5.36 & $34 \%$ & $209 \%$ \\
\hline
\end{tabular}

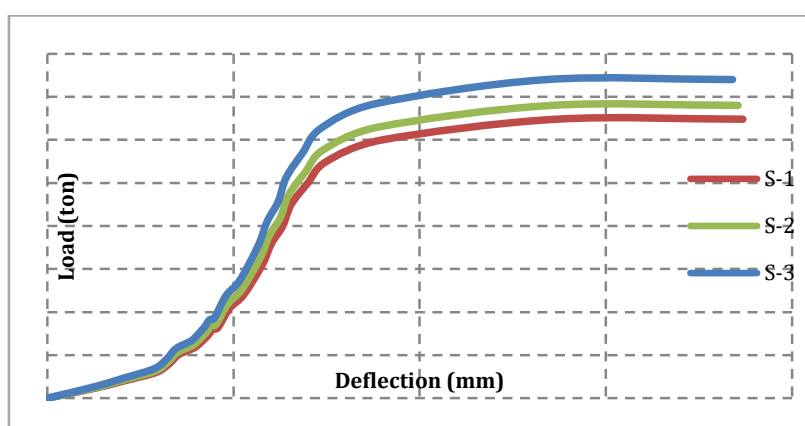

Figure 10: Relationship between Ultimate Load and Deflection for different Slab Specimens
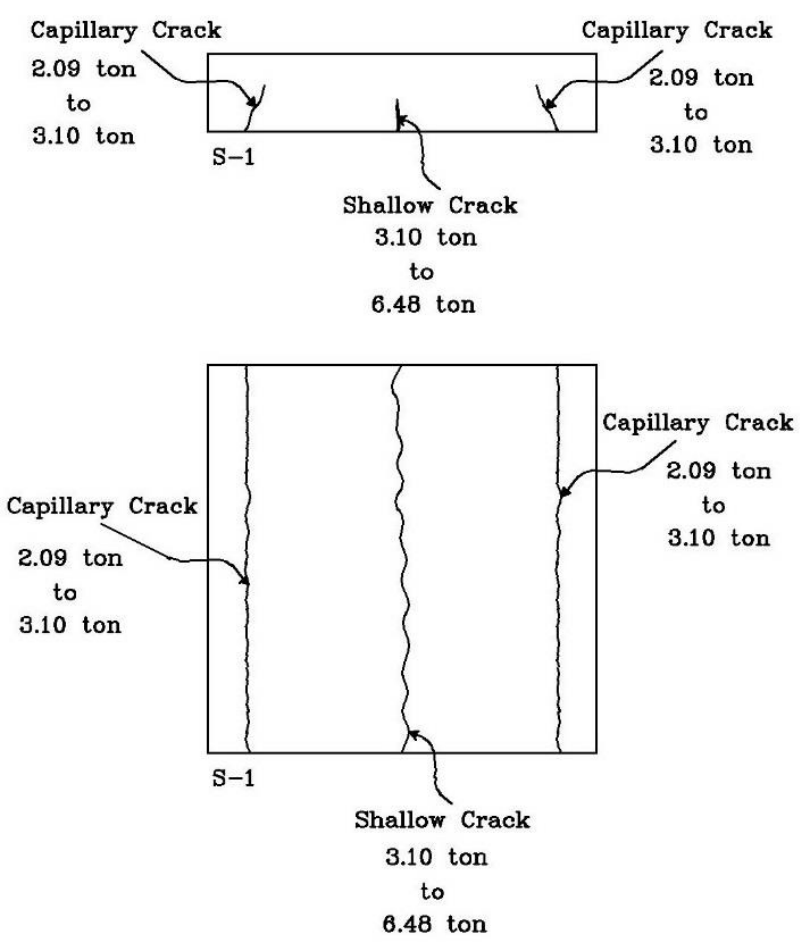

(a) 

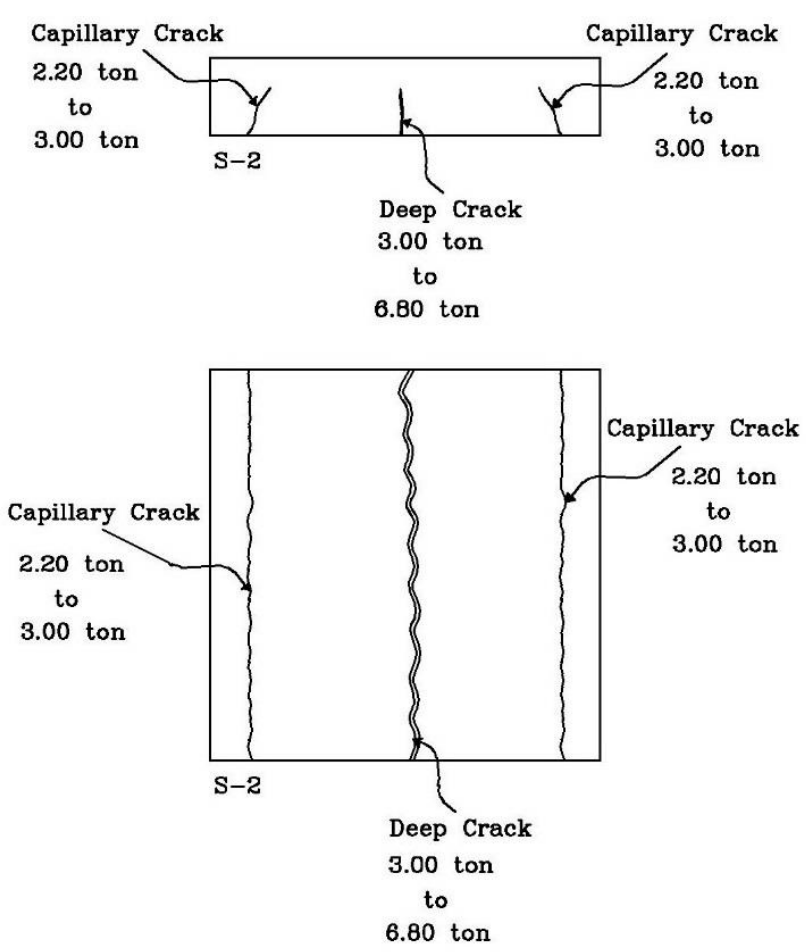

(b)
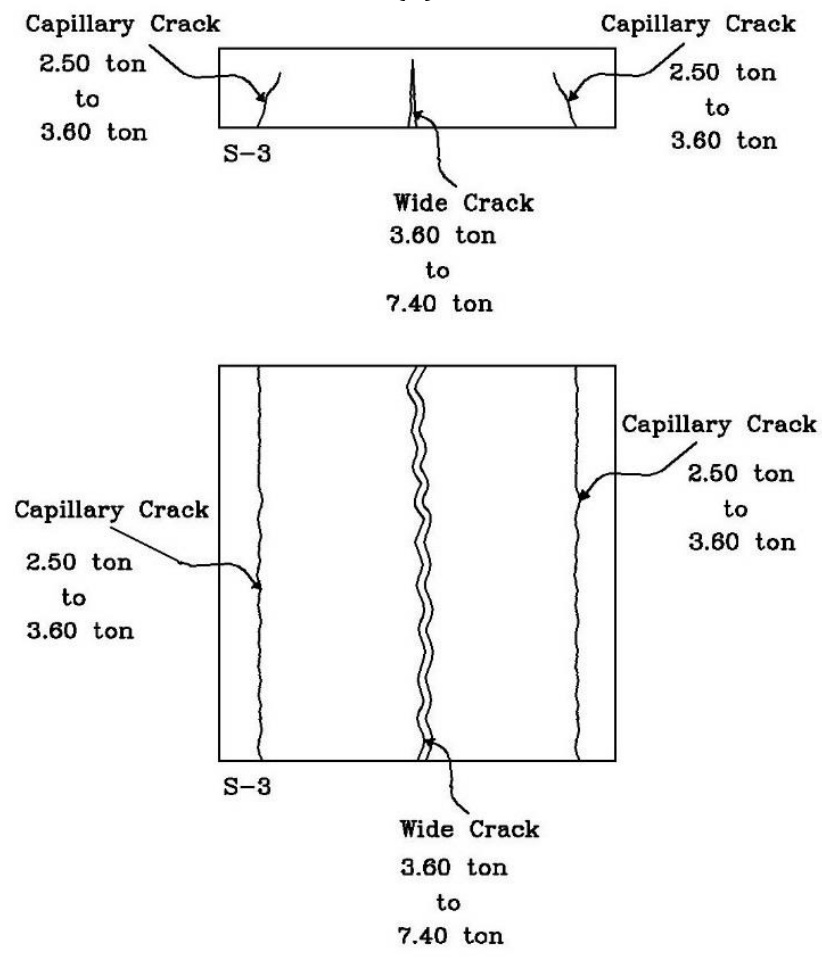

(c)

Figure 11: Crack pattern for different Slab Specimens

\section{Theoretical Analysis for Tested Specimens}

The maximum normal stresses were calculated based on obtained results in (Section 4.1.). This analysis was carried out to study the internal effect of polymer (resin) on the concrete behavior to measure the capability of its resistance to bending moment. It is worth mentioning that, normal stress of porous impregnated polymer concrete recorded 26, 27, $30 \mathrm{~kg} / \mathrm{cm}^{2}$ for cement content $200,300,400 \mathrm{~kg} / \mathrm{m}^{3}$, respectively. The results show that, polymer concrete transcend in all cases of change of cement content in concrete, and this proved by the increasing of load capacity with $1160 \%, 508 \%, 319 \%$ for studied cement contents in comparison to virgin porous concrete.

The use of porous impregnated polymer concrete is a new boom to improve the mechanical properties of the concrete, the obtained results confirmed that, using this polymer concrete will have a wide field in future research, especially given that the use of concrete without steel reinforcement bars has become the biggest concern now.

The new generation of reinforcing bars has become used fiber reinforced polymer bars. The materials which are used in polymer impregnated concrete are substantially identical with fiber reinforced polymer bars which lead to increase the bond between these bars and the concrete ingredients to get a strong high quality concrete with very high mechanical properties in comparison to any other type of modern concretes.

The following Figure (12) shows the variation of normal stress for different specimens and its seem to say that, by increasing cement content the normal stress increase but according to mix design limitations the cement content can't increase more than $500 \mathrm{~kg} / \mathrm{m}^{3}$ so that, the using of polymer (resin) is a good choice to improve without increasing of cement content. Also by increasing cement content the rate of improvement decrease so that, the optimum value with unique cost and high performance recorded at cement content $200 \mathrm{~kg} / \mathrm{cm}^{2}$

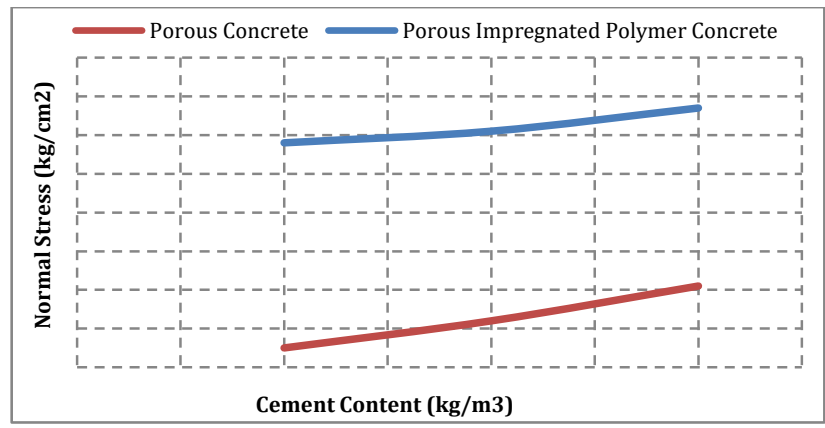

Figure 12: Normal Stress Variations

(Ali, T., \& Yehia, S., 2016) and (Yehia, S. ,2015), there are one of them having a pilot specimen with steel reinforcement area of $6.78 \mathrm{~cm}^{2}\left(6 \mathrm{Y} 12 / \mathrm{m}^{\prime}\right)$ and the other, studied a virgin traditional concrete specimen without steel reinforcement bars, both of them tested under pure bending moment and arising under the influence of the same processing of the studied conditions in this research. Common ingredients of concrete proportions are used with cement content of $350 \mathrm{~kg} / \mathrm{m}^{3}$ in these papers. The specified cement content is limited to the same interval of studied cement content in this research. By studying of the previous results, normal stress values are $108 \mathrm{~kg} / \mathrm{cm}^{2}$ (with steel rebar's) and $34 \mathrm{~kg} / \mathrm{cm}^{2}$ (without rebar's). These values are more than virgin porous concrete values by $655 \%$ and $206 \%$, respectively. On the other 
hand, the results obtained from this study achieved $60 \%$, $188 \%$ of virgin traditional reinforced/unreinforced concrete capacity when using polymer impregnated porous concrete.

\section{Conclusions and Recommendations}

This paper seeks to expand the application of polymer impregnated porous concrete to structural engineering. Density of traditional concrete is higher than porous concrete by $26 \%$ but permeability factor of porous concrete (as usual) is higher than traditional concrete by sixteen times. Although larger cement content $\left(400 \mathrm{~kg} / \mathrm{m}^{3}\right)$ achieved compressive strength of $205 \mathrm{~kg} / \mathrm{cm}^{2}$ after twenty-eight days, this value is not good deal in comparison to traditional concrete which can achieve approximately compressive strength of $350 \mathrm{~kg} / \mathrm{cm}^{2}$ for the same cement content it's need to do a unique idea to overcome low capacity of compressive strength and this appear next below. Compressive strength, indirect tensile strength and flexural strength were increased by increasing of cement content. The increase in cement content by $50 \mathrm{~kg} / \mathrm{m}^{3}$ can enhance the properties of porous concrete by approximately $288 \%, 383 \%, 324 \%$ for compressive strength, indirect tensile strength and flexural strength, respectively. It's observed that indirect tensile strength is compatible with the same percentage of compressive strength value as traditional concrete but flexure strength is out of range compared to traditional concrete. Polymer impregnated porous concrete is a suitable solution for facing low compressive strength problem. The experimental results show that increasing the cement content can't improve the behavior of polymer impregnated porous concrete slab but it can affect the failure mode due to changing in displacement ductility factor because it's gives a bond between ingredients and delay the cracking mode to appear in early state.
The ultimate load versus deflection of slabs was not changed with different cement contents so that, its recommended to use less cement content $\left(200 \mathrm{~kg} / \mathrm{m}^{3}\right)$ to be more economic without any significant decrease in capability of sustain load. For the same cement content, the capacity of polymer impregnated porous concrete increased by $188 \%$ of common unreinforced concrete and achieved $60 \%$ of virgin traditional reinforced concrete.

\section{References}

Ali, T., \& Yehia, S. (2016). Study on Strengthening of RC Slabs with Different Innovative Techniques. Open Journal of Civil Engineering, 6(4), 516-525. https:// doi.org/ 10.4236/ojce.2016. 64044

Axim, I. G. (2006). Practical Application of Previous Concrete. In Rick Blackburn (Ed.) (pp. 1-20). NRMCA Conference.

Bentz, D. P., \& Sumanasooriya, M. S. (2010). Predicting the Permeability of Pervious Concrete Advances in characterization of pore structure and transport properties, (May), 35-40.

BS: 5328, British Standard for Concrete Mix Design.

BS: 12390, British Standard for Testing Hardened Concrete.

J-FIX Polyester Resin, available at: http://jcpfixings.co.uk/ media/pdfs/COSHH/JF380P.pdf

Toy, H. C. (1924). the Permeability of Concrete. ICE Selected Engineering Papers, 1(20). https://doi.org/ 10.1680/isenp.1924.15131

Viscocrete Admixture, www.sika.com, available at: https://www.sika.com/dms/getdocument.get/73221eecfd bb368da6b294a8447d4e63/ViscoCrete.pdf

W. R. Grace\&Co.-Conn. (2006). Pervious Concrete Mix Proportioning, $0-1$.

Yehia, S. (2015). Behavior of Fibrous Light Weight Concrete in Comparison to Traditional Fibrous Concrete. International Journal of Innovative Science, Engineering \& Technology, 2(5), 113-119. 